\title{
CHARACTERISATION OF MULTICRYSTALLINE SOLAR CELLS
}

\author{
A.Q. Malik ${ }^{*}$, Chong Chew Hah, Chan Siang Khwang, Lim Chee Ming
}

Department of Physics

\author{
Tan Kha Sheng
}

Department of Engineering Science, University of Brunei Darussalam Jalan Tungku Link, Gadong BE1410, Brunei Darussalam

Received 04 July 2005

\begin{abstract}
The evaluation and assessment of the performance of photovoltaic (PV) cells in terms of measurable parameters requires the measurement of the current as a function of voltage, temperature, intensity, wind speed and spectrum. Most noticeable of all these parameters is the PV conversion efficiency $\eta$, defined as the maximum electrical power $\mathrm{P}_{\max }$ produced by the PV cell divided by the incident photon power $\mathrm{P}_{\text {in }}$ which is measured with respect to standard test conditions (STC). These conditions refer to the spectrum (AM 1.5), solar radiation intensity $\left(1000 \mathrm{Wm}^{-2}\right)$, cell temperature $\left(25 \pm 2^{\circ} \mathrm{C}\right)$ and wind speed $(2 \mathrm{mph})$. Tests under STC are carried out in the laboratory at a controlled environment. There have been several studies that analyze uncertainties in the laboratory measurement of solar cell efficiencies using different solar simulators and their transference to operational situations. Our preliminary results demonstrate that the short circuit current $\left(\mathrm{I}_{\mathrm{SC}}\right)$ of the solar cell decreases when irradiance is less than 1000 $\mathrm{Wm}^{-2}$ irrespective of the working temperature of the cell.
\end{abstract}

Keywords: Outdoor testing of solar cells by I-V and P-V; Photovoltaics, Multicrystalline

\section{INTRODUCTION}

Many photovoltaic (PV) devices show a poor performance in the field i.e. mainly in actual use conditions. Degradation in their performance is due to a variation in solar insolation, nominal operating cell temperatures and other localized microclimatic conditions [1 - 7]. The standard test conditions (STC) translate the irradiation of a clear summer day corresponding to 1000 $\mathrm{Wm}^{-2}$, the cell temperature of $25 \pm 2^{\circ} \mathrm{C}$ representing a clear winter day and the solar spectrum (AM 1.5) for a clear spring day. These measurement conditions do not reflect real operating conditions of PV device at the site of installation in the natural environment. For the optimum design of PV power systems, it is desirable to measure their working performances at the site of

\footnotetext{
* Corresponding author e-mail: aqmalik@fos.ubd.edu.bn
} 
installation. The objective of the present study is to investigate the performance characteristics of multicrystalline solar cells in the Brunian climate.

\section{EXPERIMENTAL PROCEDURES}

Figure 1 is a schematic circuit diagram for the measurement of current and voltage of a solar cell. A polycrystalline (multicrystalline) solar cell was mounted horizontally on a specially designed stand and placed on the roof of the physics laboratory at Universiti Brunei Darussalam. The insolation, ambient temperature and wind speed were recorded at the time of starting and completing the experiment. The Variable Bipolar Power Supply was used for obtaining the short circuit current, $\mathrm{I}_{\mathrm{SC}}$, open-circuit volatge, $\mathrm{V}_{\mathrm{OC}}$, and the maximum power, $\mathrm{P}_{\max }$. The cell voltage is measured by connecting a Fluke digital multimeter (73 III Multimeter) across it. The load current, which is the current generated by the solar cell and passing through the circuit was obtained by measuring the voltage across the shunt resistor $(0.01 \mathrm{ohms})$ with the use of a Fluke digital multimeter (87 AV True rms Multimeter). This voltage was then converted to current. The voltage across the load resistance was measured instead of current because the available digital meters are not sensitive enough to record a small change in the current. The value of $\mathrm{P}_{\max }$ was calculated by multiplying voltage and load current of the solar cell.

The experiment was carried out once a week on every Saturday at 09:30 - 10:00, 12:00 - 12:30 (solar noon) and 14:30 - 15:16 local standard time in the months of January, February and March 2003. Solar noon is the time when the Sun is at the zenith position and this is the time that divides the day exactly into two equal parts and maximum irradiance is obtained, as the sun is directly above the Earth's surface. The reason for conducting two tests before and after the solar noon, was to study the effect of variation in insolation and corresponding rise in temperature on the performance of the soar cell in outdoors testing.

\section{RESULTS AND DISCUSSION}

A multicrystalline silicon solar cell was mounted horizontally on a stand and placed under the sun on the roof of the Physics Laboratory of University of Brunei Darussalam. The outdoors testing of the cell was carried out once a week for a period of 3 months (January - March 2003). The test was conducted near the solar noon (corresponds to 12:00 hours local standard time) and approximately two hours before and after it. The performance of the solar cell is characterised in terms of the current-voltage (I-V) curve. The characteristics of the solar cell under study at STC are summarized in Table 1 and are compared to those obtained in the natural environment. When the voltage of the solar cell is made zero the highest current is obtained and this is known as the short-circuit current, $\mathrm{I}_{\mathrm{SC}}$. Power is voltage times current and in this case since the voltage is zero thus the output power will also be zero. When the voltage is slowly increased, the current will stay relatively constant and this will result in the power produced increasing also. However by increasing the voltage further there will be a stage where the current will start to drop until it reaches zero, and the voltage obtained is the highest. This voltage is termed as open-circuit voltage, $\mathrm{V}_{\mathrm{OC}}$. The power at this point is also zero as the current is zero. By plotting the P-V curve of the solar cell, it can be seen that the maximum power obtained is between the shortcircuit current and the open-circuit voltage. This peak power is called $\mathrm{P}_{\max }$ and it is identified by the voltage $\mathrm{V}_{\max }$ and current $\mathrm{I}_{\max }$ values.

Table 1: $\quad$ The parameters of polysilicon solar cell at standard test conditions (STC) obtained from manufacturer 


\begin{tabular}{|l|c|}
\hline \multicolumn{1}{|c|}{ Parameter } & At STC \\
\hline Insolation & $1000 \mathrm{~W} / \mathrm{m}^{2}$ \\
\hline Cell Temperature & $25^{\circ} \mathrm{C} \pm 2^{\circ} \mathrm{C}$ \\
\hline Wind speed & $2 \mathrm{mph}$ \\
\hline $\mathrm{I}_{\mathrm{SC}}$ & $0.762 \mathrm{~A}$ \\
\hline $\mathrm{V}_{\text {OC }}$ & $10.3 \mathrm{~V}$ \\
\hline $\mathrm{V}_{\max }$ & $8.2 \mathrm{~V}$ \\
\hline $\mathrm{I}_{\max }$ & $0.705 \mathrm{~A}$ \\
\hline $\mathrm{P}_{\max }$ & $5.83 \mathrm{~W}$ \\
\hline $\mathrm{P}_{\text {in }}$ & $45.9 \mathrm{~W}$ \\
\hline Fill Factor & 0.743 \\
\hline Cell Efficiency $\eta$ & $12.7 \%$ \\
\hline
\end{tabular}

Ideally the solar cell would always operate at this point as it produces the maximum power. However, the solar radiation falling on the solar cell and the temperature of the cell always changes thus it would cause a change in the I-V curve and thus affect the P-V curve. Besides this, the amount of solar radiation falling on the solar cell and the ambient temperature were also measured. These data were used to estimate the efficiency $(\eta)$ of the solar cell. The I-V curve is very useful for locating faults by checking for oddness in its shape. Then these faults can be traced and corrected. For rating purposes, however, it is necessary to transpose the measured characteristics to Standard Test Conditions (STC), which are as follows:
Cell's temperature:
$25 \pm 2{ }^{\circ} \mathrm{C}$
Irradiance (Solar radiation falling on the solar cell):
$1000 \mathrm{Wm}^{-2}$
Spectral Irradiance:
AM1.5 ${ }^{*}$
Wind speed:
$2 \mathrm{mph}$

Full I-V and P-V curves for multicrystalline solar cells under investigation at STC have not been presented due to the lack of indoor test facilities.

(* In accordance with the AM 1.5 specified in ASTM (E 1036) by Kazmerski [8]).

The advantage of outdoor measurements in natural sunlight is that it provides the environment in which the solar cell is going to be operated, while indoor measurements with the use of a solar simulator (STC) have the advantage of offering more accurate control of irradiance level, cell temperature and spectral distribution, and better repeatability of test conditions. In this project the spectrum distribution of solar radiance and its seasonal changes were not taken into account for the correction of efficiency.

The working temperature of the solar cell $\left(\mathrm{T}_{\mathrm{c}}\right.$ ) depends exclusively on the irradiance, $\mathrm{G}$ (in $\mathrm{Wm}^{-2}$ ) and on the ambient temperature $\left(\mathrm{T}_{\mathrm{a}}\right)$. A set of equations was used to estimate the solar cell temperatures in open environment (Lorenzo, E; [9], Malik and Salmi; [10], Malik et al. [11] and Sayigh; [12]).

Six tests were conducted in the month of January $\left(18^{\text {th }}\right.$ and $\left.25^{\text {th }}\right) 2003$ and the results for one of these are shown in Fig. 2. Three experiments were carried out every Saturday at 09:30-10:00, 
12:00 - 12:30 and 14:30 - 15:16 hours local standard time. These times correspond to solar noon (12:00 - 12:30), and approximately 2 hours before and after the solar noon. All these tests were restricted to 15 minutes duration as:

- $\quad$ Sometimes, there was drastic variation in the amount of solar radiation.

- $\quad$ The voltage drops across the solar cell and the shunt resistance have been measured manually using digital multimeters. It was difficult to accommodate the sudden unforeseen variations in the solar radiations due to cloud cover in the sky and their corresponding effects on the measured voltages. The voltage drop in the shunt resistance was then used to calculate the current flowing through the cell.

A maximum conversion efficiency of 29.9\% was recorded for January 25, 2003 at 15:00-15:16 hours. The sky was cloudy, solar irradiance and cell temperature were $500-800 \mathrm{~W} / \mathrm{m}^{2}$ and $51.1^{\circ} \mathrm{C}$ respectively. The amount of solar radiation falling on the solar cell was almost $35 \%$ less than that of $1000 \mathrm{~W} / \mathrm{m}^{2}$, and the rise in the cell temperature was $26.1^{\circ} \mathrm{C}$ compared with that at which the solar cell was tested at STC. The recorded efficiency of the cell was much higher than that compared with the efficiency measured at STC (see Table 1).

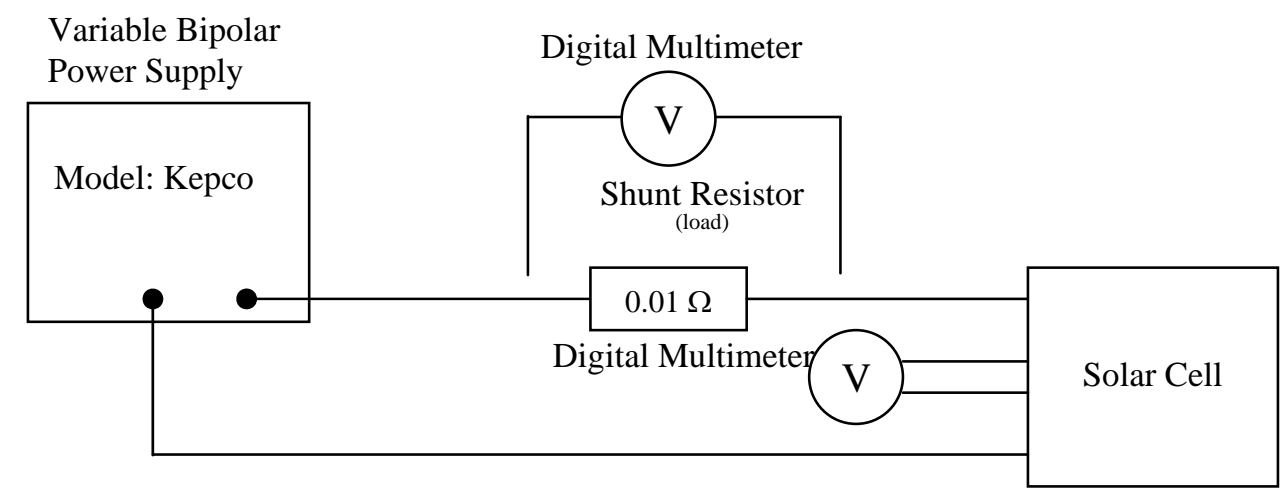

Fig. 1: A schematic circuit diagram for measurement of the current and voltage of a solar cell used in this project. The voltage (V) drop across the shunt resistance was measured using a Fluke Digital Multimeter that was then converted using Ohm's laws $V=I R(R=0.01 \Omega)$

A minimum estimated efficiency of $10.8 \%$, on the other hand, was recorded for January 18 , 2003 at 09:35 - 10:02 hours. An average solar radiation of $300 \mathrm{~W} / \mathrm{m}^{2}$ and cell temperature of $38.8^{\circ} \mathrm{C}$ are responsible for the drop in efficiency. The amount of solar radiation captured by the cell was about $70 \%$ less than the $1000 \mathrm{~W} / \mathrm{m}^{2}$ (insolation at STC) and the cell temperature was about $13.8^{\circ} \mathrm{C}$ more than the STC cell temperature, which is at $25^{\circ} \mathrm{C}$. Thus resulted in the recorded efficiency being $15 \%$ less compared with standard temperature condition.

The average efficiency of the polysilicon solar cell for the month of January is $19.3 \%$. The monthly-averaged insolation was $730 \mathrm{~W} / \mathrm{m}^{2}$ and the average cell temperature was about $51.1^{\circ} \mathrm{C}$. All these values vary differently when compared with rating at STC. The average solar insolation was $27 \%$ less, whereas the cell temperature and efficiency were $26.1^{\circ} \mathrm{C}$ and $52 \%$ more than that at STC respectively. 

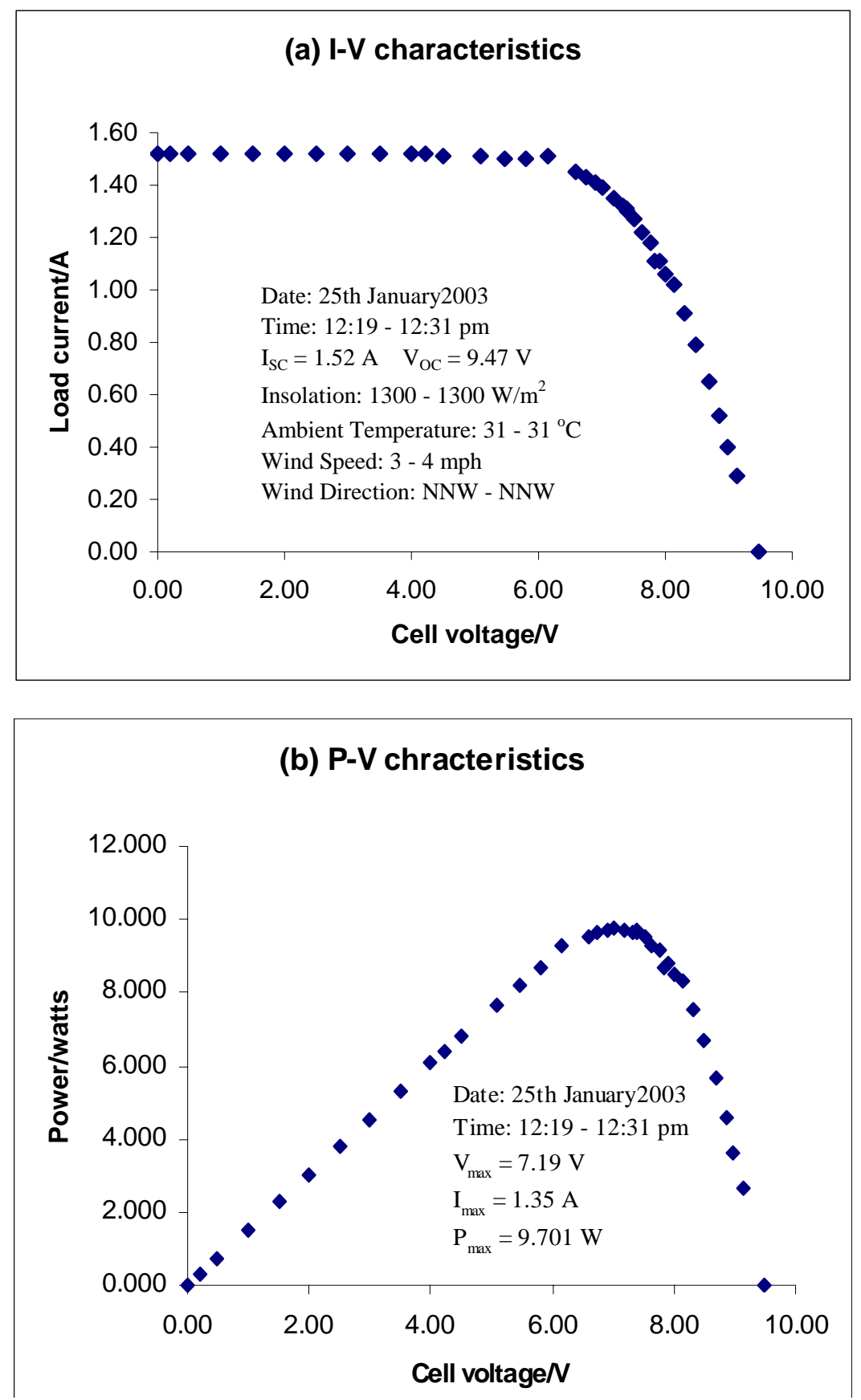

Fig. $2(\boldsymbol{a} \& \boldsymbol{b})$ : $\quad$ Measured outdoor characteristics of poly (multi) crystalline solar cell in the month of January 2003. The solar cell under investigation was placed horizontally under the sun on the roof of physics laboratories at University of Brunei Darussalam 

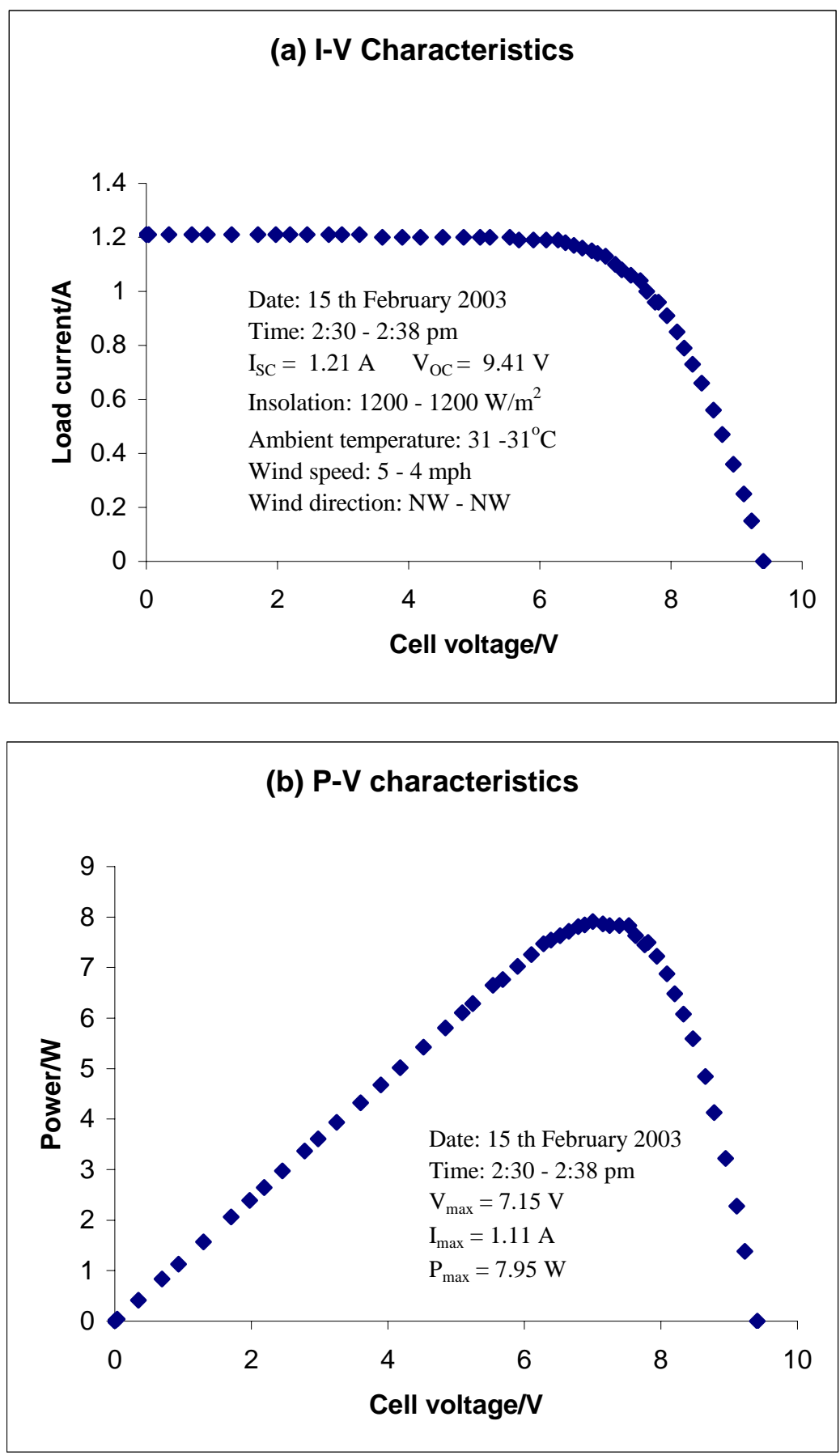

Fig. $3(\boldsymbol{a} \& \boldsymbol{b})$ : $\quad$ Measured outdoor characteristics of poly (multi) crystalline solar cell in the month of February 2003. The solar cell under investigation was placed horizontally under the sun on the roof of physics laboratories at University of Brunei Darussalam 

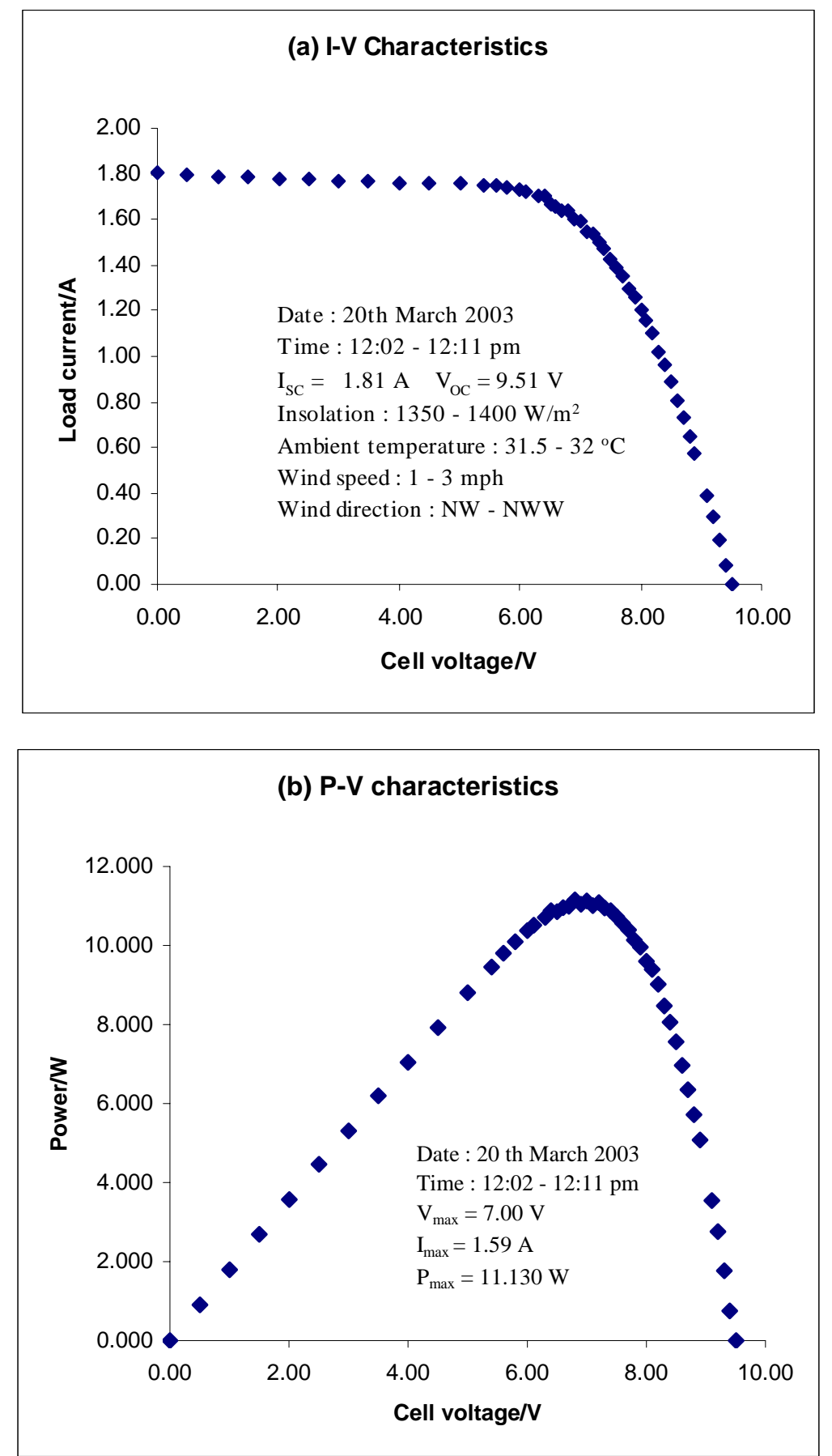

Fig. 4 ( $\boldsymbol{a} \& \boldsymbol{b}$ ): $\quad$ Measured outdoor characteristics of poly (multi) crystalline solar cell in the month of March 2003. The solar cell under investigation was placed horizontally under the sun on the roof of physics laboratories at University of Brunei Darussalam 
As for the month of February, nine tests $\left(8^{\text {th }}, 15^{\text {th }}, 22^{\text {nd }}\right)$ were conducted. The results of one of these are shown in Fig. 3. For this month, a maximum conversion efficiency of $17 \%$ was obtained at the solar noon on the $8^{\text {th }}$. The sky was very cloudy, the solar irradiance was 250 $500 \mathrm{~W} / \mathrm{m}^{2}$ and the cell temperature was $41^{\circ} \mathrm{C}$. On average, the amount of solar radiation falling on the solar cell was about $63 \%$ less than that at the STC, while the cell temperature was about $16^{\circ} \mathrm{C}$ more. This resulted in the recorded efficiency of the cell to be about $34 \%$ more efficient than that at STC. This is because of the fact that an increase in the cell temperature, reduces $\mathrm{V}_{\mathrm{OC}}$ and increases $\mathrm{I}_{\mathrm{SC}}$ of the solar cell.

A minimum conversion efficiency of $12.2 \%$ was recorded on the $22^{\text {nd }}$ February at 09:32-09:52 hours. The average insolation for this test was $1000 \mathrm{~W} / \mathrm{m}^{2}$ and the cell temperature was about $61.5^{\circ} \mathrm{C}$ that is $36.5^{\circ} \mathrm{C}$ greater than the STC. The rise in the cell temperature slightly decreases the $\mathrm{V}_{\mathrm{OC}}$ and increases $\mathrm{I}_{\mathrm{SC}}$ that cause the efficiency of the cell to drop by about $3.9 \%$.

The average insolation recorded for the month of February is $1050 \mathrm{~W} / \mathrm{m}^{2}$ i.e. approximately $5 \%$ more than the STC insolation. The monthly average working cell temperature was $64^{\circ} \mathrm{C}$ i.e. $39^{\circ} \mathrm{C}$ greater than the $25^{\circ} \mathrm{C}$ cell temperature at STC. This resulted in the average efficiency of solar cell a slightly greater than that at STC. The calculated average efficiency was about $14.8 \%$ i.e. about $16.5 \%$ more efficient than that at STC. This increase in the efficiency of solar cell is due to the change in the working voltage and current of the cell at different operating temperatures.

In March, 17 experiments $\left(1^{\text {st }}, 15^{\text {th }}, 20^{\text {th }}, 21^{\text {st }}, 22^{\text {nd }}, 29^{\text {th }}\right)$ were carried out. Out of 17 tests, the results of one of these shown graphically in Fig. 4. The maximum conversion efficiency of 29.3\% was recorded on the 20th of March at 09:32 - 09:40 hours when there was a thick cloud covering the sun. The solar irradiance and cell temperature were $180-200 \mathrm{~W} / \mathrm{m}^{2}$ and $35.2^{\circ} \mathrm{C}$ respectively. The amount of solar radiation falling on the solar cell was almost $81 \%$ less than that of $1000 \mathrm{~W} / \mathrm{m}^{2}$, and the rise in the cell temperature was $10.2^{\circ} \mathrm{C}$ compared with that at which the solar cell was tested at STC. The recorded efficiency of the cell was much higher than that compared with the efficiency measured at STC (see Table 1).

The minimum efficiency for the whole month of March was recorded at $14.2 \%$ on the 22nd at 09:32 - 09:39 hours. The sky at that time was slightly cloudy and the solar irradiance was 900 $950 \mathrm{~W} / \mathrm{m}^{2}$ with the cell temperature at $61.1^{\circ} \mathrm{C}$. By comparing these two values to that at STC, the cell temperature was $36.1^{\circ} \mathrm{C}$ higher while the drop in solar irradiance was $7.5 \%$. This resulted in a slight increase of $11.8 \%$ in the efficiency of solar cell compared with that at STC.

The monthly-averaged efficiency of the solar cell is $17.9 \%$. The average insolation and cell temperature were $852 \mathrm{~W} / \mathrm{m}^{2}$ and $57.5^{\circ} \mathrm{C}$ respectively. The average insolation was $14.8 \%$ less, whereas the cell temperature and efficiency were $32.7^{\circ} \mathrm{C}$ and $40.9 \%$ more than that at STC respectively. The change in the efficiency of the solar cell is due to its working temperature. An increase in the temperature decreases $\mathrm{V}_{\mathrm{OC}}$ very slightly while the increase in the $\mathrm{I}_{\mathrm{SC}}$ is more compared with the change in the $\mathrm{V}_{\mathrm{OC}}$. These two effects together produce a big change in the efficiency of the solar cell.

The dependence of the working temperature of multicrystalline solar cells on $I_{s c}, V_{o c}$ and $P_{\max }$ has been investigated by many researchers at STC and in the field [13 - 18]. The recent studies on the chracterisation of multicrystalline solar cells in natural sunlight carried out by the research group at University of Brunei Darussalam reported that the values of three temperature coefficients $\alpha\left(\equiv \frac{d V_{o c}}{d T}\right), \beta\left(\equiv \frac{d I_{s c}}{d T}\right)$ and $\gamma\left(\equiv \frac{d P_{\max }}{d T}\right)$ are $-0.019 \mathrm{~V} /{ }^{\circ} \mathrm{C}, 0.011 \mathrm{~A} /{ }^{\circ} \mathrm{C}$ and $0.05904 \mathrm{~W} /{ }^{\circ} \mathrm{C}$ respectively [18]. The effect of ageing on the performance of crystalline solar cells in the Bruneian climate is being investigated. 
Preliminary results demonstrate that the operating temperature of the cell is one of the most important parameters affecting the solar cell power and its efficiency of conversion of sunlight into electricity. The output of the solar cell and module decreases with increase of the cell temperature. It is a function of the incident radiation as well as ambient temperature, thermal properties of cell encapsulation and the thermal effects of the mounting structure. In order to reduce the cell temperature to get near the rated value for maximum efficiency, a cost effective solution would need research for encapsulation material and cost analysis (Gonzalez and Carroll, [13]).

Long term outdoor testing of solar cells is required to study the seasonal effects on the performance of PV solar cells. It has been observed that during a test with the present experimental set up it is difficult to accommodate any sudden and unforeseen major change(s) in the amount of solar radiation falling on the surface of solar cells. It is, therefore, desirable to improve the measurement techniques for open circuit voltage and short circuit current. This can be achieved in the future by employing an A/D converter, which is much faster in accommodating micro climatic changes.

The measurement of the operating temperature of the solar cells is another important parameter influencing the performance of these cells and it could be improved by using temperature sensors. This would help to accurately study the influence of temperature on the ratings of the solar cells.

\section{CONCLUSIONS}

The results obtained demonstrate that the output power of a polycrystalline solar cell is reduced as irradiance is reduced; the efficiency of these cells is increased as irradiance increases; and the open circuit voltage, $\mathrm{V}_{\mathrm{OC}}$, of the solar cells decreases as the working temperature of the cell increases. But no definite correlation between them was found.

It has been noted that the short circuit current $\left(\mathrm{I}_{\mathrm{SC}}\right)$ of the solar cell decreases when irradiance is less than $1000 \mathrm{Wm}^{-2}$ irrespective of the working temperature of the cell. While an increase in the short circuit current $\left(\mathrm{I}_{\mathrm{SC}}\right)$ has been observed at irradiance greater than $1000 \mathrm{Wm}^{-2}$.

At higher working temperatures with irradiance greater than $1000 \mathrm{Wm}^{-2}$ an increase in the short circuit current and a reduction in open circuit voltage increases the efficiency of the polycrystalline solar cell. This result indicates that multicrystalline solar cells may be the better choice for power production in those regions of the globe having similar climatic conditions to Brunei Darussalam. The short circuit current and open circuit voltage are very complex functions of the working temperature of solar cells and of the intensity of solar radiation. In the present study no any definite dependence among these parameters has been established.

\section{ACKNOWLEDGEMENTS}

We wish to thank Universiti Brunei Darussalam for financial support through a research grant $\mathrm{UBD} / \mathrm{PNC} 2 / 2 / \mathrm{RG} / 1(32)$.

\section{REFERENCES}

1. Gonzalez, M.C. and Carroll, J.J. (1994), Solar Cells efficiency Variations with Varying Atmospheric Conditions, Solar Energy, vol. 53, no. 5, pp. 395-402.

2. Shaltout, M.A.M, Mahrous, A.M., Ghettas, A.E., and Fattah, Y.H. (1995), Photovoltaic 
Performance under Real Desert Conditions near Cairo, Renewable Energy, vol. 6, no. 5-6, pp. 533-536.

3. Hirata, Y. and Tani, T. (1995), Output Variation of Photovoltaic Modules with Environmental Factors-I, The Effect of Spectral Solar Radiation on Photovoltaic Module Output. Solar Energy, vol. 55, no. 6, pp. 463-468.

4. Al-Sabounchi, A.M. (1998), Effect of Ambient Temperature on the Demanded Energy of Solar Cells at Different Inclinations. Renewable Energy, vol. 14, no. 1-4, pp. 149-155.

5. Hirata, Y., Inasaka, T., and Tani, T. (1998), Output Variation of Photovoltaic Modules with Environmental Factors-II: Seasonal Variation, Solar Energy, vol. 63, no. 3, pp. 185189.

6. Berman, D., Faiman, D., and Farhi, B. (1999), Sinusoidal Spectral Correction for High Precision Outdoor Module Chracterisation. Solar Energy Materials \& Solar Cells, vol. 58, pp. 253-264.

7. Keogh, W.M. and Blakers, A.W. (2004), Accurate Merasurement, Using Natural Sunlight, of Silicon Solar cells, Prg. Photovolt: Res. Appl. vol. 12, pp. 1-19.

8. Kazmerski, L.L. (1997), Photovoltaics: Review of Cell and Module Technologies. Renewable and Sustainable Energy Reviews, vol. 1, no. 1-2, pp. 71-170.

9. Lorenzo, E. (1994), Solar Electricity Engineering of Photovoltaic Systems, Institute of Solar Energy Polytechnic University of Madrid, University Press: Spain.

10. Malik, A.Q. and Salmi Jan Bin Haji Damit (2003), Outdoor Testing of Single Crystal Silicon Solar Cells, Renewable Energy, vol. 28, no. 9, pp. 1433-1445.

11. Malik, A.Q., Joanne Lee Siew Peng, Sarisavinarinawatie Shahrani Muhammad, Tan Kha Sheng, and Lim Chee Ming, Outdoor Measurements of Photovoltaic Solar Cells, Published, In: Technical Digest of the $14^{\text {th }}$ International Photovoltaic Science and Engineering Conference (PVSEC-14), Bangkok, Thailand, 2004, ISBN No. 974-91703-9-9, vol. 2, pp. 803-804.

12. Sayigh, A.A.M. (1991), Generating Electricity from the Sun. Renewable Energy Series. Pergamon Press: Oxford, U.K.

13. Gonzalez, M.C. and Carroll, J.J. (1994), Solar Cells Efficiency Variations with Varying Atmospheric Conditions. Solar Energy, vol. 53, no. 5, pp. 395-402.

14. Green, M.A. (2003), General Temperature Dependence of Solar Cell Performance and Implications for Device Modelling, Prog. Photovolt: Res. Appl. vol. 11, pp. 333-340.

15. Raziemska, E. and Klugmann, E. (2002), Thermally Affected Parameters of the CurrentVolatge Chracteristics of Silicon Photocell. Energy Conversion \& Management, pp. 18891900.

16. Dyk, E.E.V., Scott, B.J., Meyer, E.L., and Letch, A.W.R. (2000), Temperature Dependence of Performance of Crystalline Silicon Photovoltaic Modules, South African Journal of Science, vol. 96, pp. 198-200.

17. Mattei, M., Notton, G., Cristofari, C., Muselli, M., and Poggi, P. (2006), Calculation of the Polycrystalline PV Module Temperature using a Simple Method of Energy Balance, Renewable Energy, vol. 31, pp. 553-567.

18. Malik, A.Q., Lim Chee Ming, and Tan Kha Sheng (2006), The Effect of Temperature on the Power Output of Photovoltaic Solar Cells, Accepted for presentation at World Renewable Energy Congress-IX, 19-25 August, Florence, Italy. 